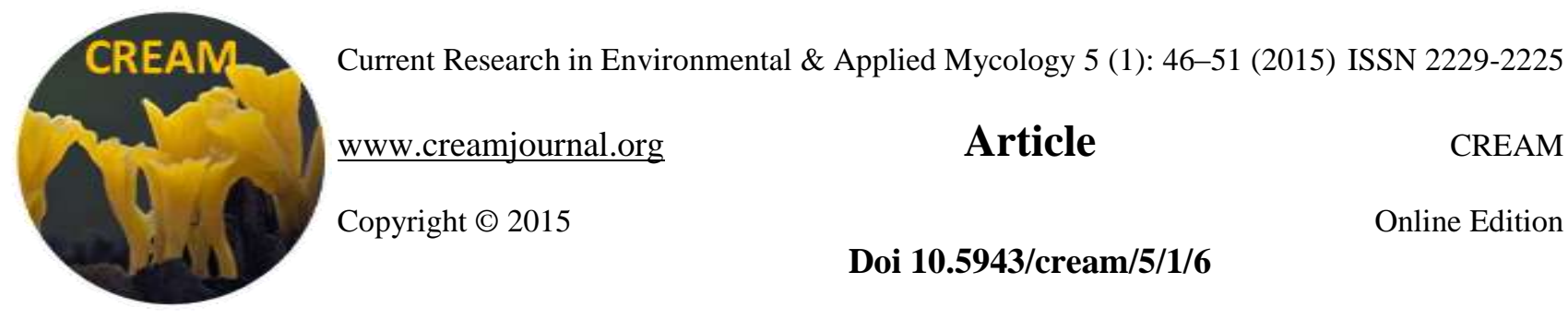

\title{
Three new records of black mildew fungi from India
}

\section{Bhise $\mathrm{MR}^{\mathbf{1}^{*}}$, Patil $\mathrm{CR}^{2}$ and Salunkhe $\mathrm{CB}^{1}$}

${ }^{1}$ PG Department of Botany, Krishna Mahavidhyalaya, Shivnagar, Rethare (BK.), Dist. Satara-415108, Maharashtra, India.

${ }^{2}$ Department of Botany, Dattajirao Kadam Arts, Science and Commerce College, Ichalkaranji, Dist. Kolhapur - 416115, Maharashtra, India.

Bhise MR, Patil CR, Salunkhe CB 2015 - Three new records of black mildew fungi from India. Current Research in Environmental \& Applied Mycology 5(1), 46-51, Doi 10.5943/cream/5/1/6

\begin{abstract}
The present paper deals with three new records of black mildew fungi belonging to Meliolales, collected on different host plants from Mahabaleshwar, Maharashtra, India. These are, Meliola luzonensis, M. sideroxyli and M. ventilaginicola reported for the first time from India on hitherto unreported hosts.
\end{abstract}

Key words - Meliola - Mahabaleshwar - Maharashtra - Western Ghats

\section{Introduction}

Mahabaleshwar is situated in Satara district of Maharashtra state (India), clad in subtropical evergreen and semi-evergreen forests with high biodiversity. A wide range of plant communities and the richness of higher plants provide favorable conditions for growth of black mildew fungi.

Meliolaceous fungi are commonly known as 'Black or dark mildews', which are mostly occurring on wild plants and are less destructive to plants and hence received less attention. These fungi are generally foliicolous, obligate, superficial, host specific and characterised by the presence of two celled appressoria formed on mycelium, phialides, mycelial setae, perithecioid ascomata and 3 to 4 septate ascospores (Hansford 1961). In the world, the rich diversity of meliolaceous fungi (ca. 745) found in India (Hosagoudar 1996, 2008, 2013).

During the exploration of meliolaceous fungi from Mahabaleshwar, three species are found to be new records for India. These species are for the first time reported on new host's viz. Meliola luzonensis Syd. on Dimorphocalyx lawianus (Muell.-Arg.) Hook. (Euphorbiaceae), M. sideroxyli Stev. on Xantolis tomentosa (Roxb.) Raf. (Sapotaceae) and M. ventilaginicola Hansf. on Ventilago denticulata Willd. (Rhamnaceae). The detail morphological description, beeli's digital formula, colour photographs, line drawings and discussions are provided here for each species.

\section{Materials and Methods}

The leaves and twigs of host plants, infected with black mildews were collected from study area during winter (2012-2014). Host plants were identified using the regional flora (Deshpande et al. 1995). The specimens were air-dried and preserved in standard size herbarium packets. Both macro and micro-morphological characters are only used for taxonomical studies of collected fungi. Microscopic preparations were made in lactophenol and observed under compound light microscope. To observe mycelial branching and position of appressoria, a drop of peeling solution 
(Xylene-Thermocol solution) was applied on selected colonies, and after drying, the film was mounted directly again in the same solution. The fungal specimens were identified and their distributional records were checked by using standard literature (Hansford 1961, Bilgrami et al. 1981, 1991, Hosagoudar 1996, 2008, 2013, Hosagoudar et al. 1997, Jamaluddin et al. 2004, Hosagoudar \& Agarwal 2008, Far \& Rossman 2014). Illustrations are prepared with Camera Lucida and photographed under Leica DM2000 fluorescence microscope equipped with digital camera. Identified specimens are deposited in Herbarium Cryptogamae Indiae Orientalis (HCIO), IARI, New Delhi (India) for their accession.

\section{Results}

\section{Taxonomy}

Meliola luzonensis Syd., Ann. Mycol. 15: 188, 1917; Hansf., Sydowia Beih. 2: 222, 1961.

Beeli formula - 3113:3223

(Figs. 1-9)

Colonies epiphyllous, dark brown, thin, effused, circular to spreading, confluent, up to $4 \mathrm{~mm}$ in diameter. Hyphae straight to substraight, dark brown, branching opposite to alternate at wide angles, loosely reticulate; cells 16-32 × 7-9 $\mu \mathrm{m}$. Appressoria opposite to alternate, antrorse, closely arranged, straight to slightly curved, 13-16 $\mu \mathrm{m}$ long; stalk cells cylindrical to cuneate, 4-5 $\times 7-9$ $\mu \mathrm{m}$; head cells globose, ovate to oblong, entire, 9-13 $\times 9-14 \mu \mathrm{m}$. Phialides mixed with appressoria, alternate to opposite, sometimes opposite to appressoria, ampulliform, 18-27 $\times 6-7 \mu \mathrm{m}$. Mycelial setae numerous, scattered, simple, straight, acute to pointed at the tip, up to $659 \mu \mathrm{m}$ long. Perithecia globose, scattered, verrucose at margin, up to $165 \mu \mathrm{m}$ in diameter. Ascospores oblong to cylindrical, olivaceous brown, 4-septate, constricted at septum, 32-36 × 13-16 $\mu \mathrm{m}$.

Materials examined - India, Maharashtra, Mahabaleshwar, Pratapgad, on leaves of

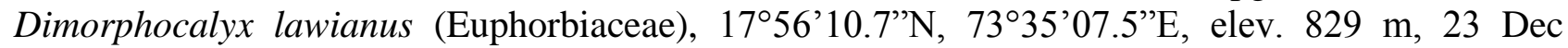
2012, Bhise M.R., HCIO 51740.

Known distribution - Philippines (Hansford, 1961) and India (the present record).

Notes - Meliola luzonensis was known on Antidesma sp. from Philippines (Hansford 1961, Far \& Rossman 2014). The present collection matches well with the type description of $M$. luzonensis, but varies in having smaller mycelial setae (in contrast up to $900 \mu \mathrm{m}$ long). However, the present species is reported here for the first time from India on hitherto unrecorded host.

Meliola sideroxyli Stev., Bull. Bishop Mus. 19: 35, 1925; Hansf., Sydowia Beih. 2: 504, 1961.

Beeli formula - 3113:4223

(Figs. 10-18)

Colonies amphigenous, thin, brown, effused, circular to spreading, confluent, up to $8 \mathrm{~mm}$ in diameter. Hyphae straight to substraight, branching opposite at wide angles, loosely to closely reticulate; cells 22-36 × 5-7 $\mu \mathrm{m}$. Appressoria opposite to alternate, mostly opposite, closely arranged, antrorse to subantrorse, straight to slightly recurved, 13-16 $\mu \mathrm{m}$ long; stalk cells cylindrical to cuneate, 4-5 × 5-7 $\mu \mathrm{m}$ long; head cells globose to oblong, entire, 9-13 $\times 7-9 \mu \mathrm{m}$. Phialides mixed with appressoria, alternate to opposite, ampulliform, 16-20 $\times 7 \mu \mathrm{m}$. Mycelial setae numerous, closely scattered, simple, straight, acute to pointed at the tip, up to $808 \mu \mathrm{m}$ long. Perithecia globose, scattered, verrucose at margin, up to $193 \mu \mathrm{m}$ in diameter. Ascospores oblong to cylindrical, pale brown to dark brown, 4-septate, constricted at the septum, 41-47 × 13-18 $\mu \mathrm{m}$.

Materials examined - India, Maharashtra, Mahabaleshwar, Gonoshi forest, on leaves of Xantolis tomentosa (=Sideroxylon tomentosum, Sapotaceae), 1755'22.3'N, 73³6'02.4'”, elev. 690 m, 04.02.2014, Bhise M.R., HCIO 51801.

Known distribution - Hawaii and Cuba (Hansford, 1961) and India (the present record).

Notes - Meliola sideroxyli was known on Sideroxylon sp. from Hawaii and Cuba (Hansford 1961, Far \& Rossman 2014). The present collection matches well with the type description of $M$. 

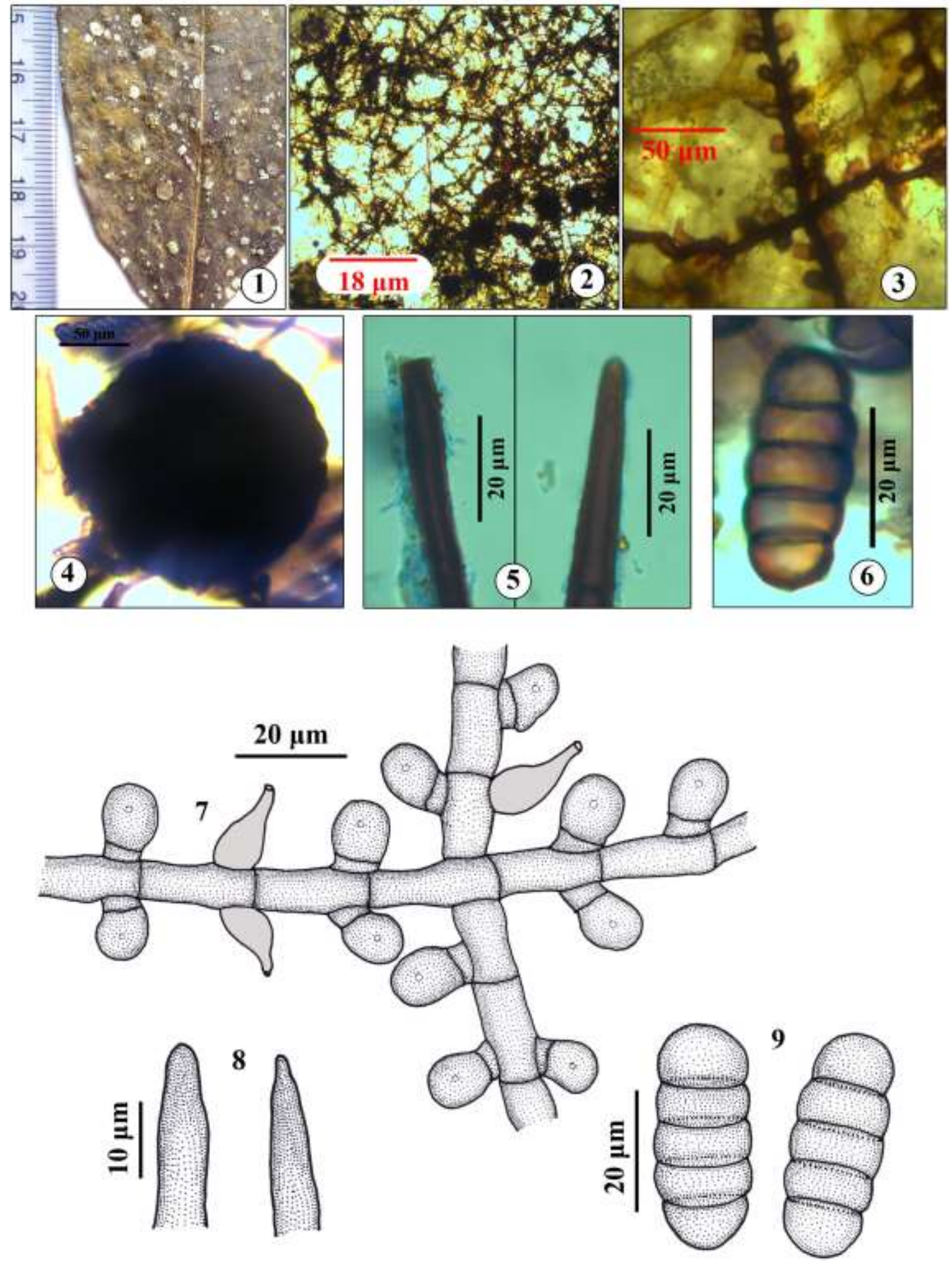

Figs 1-9-Meliola luzonensis. 1 Infected leaves. 2 Mycelial colony. 3, 7 Appressoriate mycelium with phialides. 4 Perithecium. 5, 8 Tip of mycelial setae. 6, 9 Ascospores.

sideroxyli, but, varies in having slightly larger hyphae cells (in contrast 10-20 $\times 5-7 \mu \mathrm{m}$ ) and longer mycelial setae (in contrast up to $600 \mu \mathrm{m}$ long). However, the present species is reported here for the first time from India and found to be associated with Asteridiella sapotacearum Hansf. and Asterina laxiuscula Sydow. 

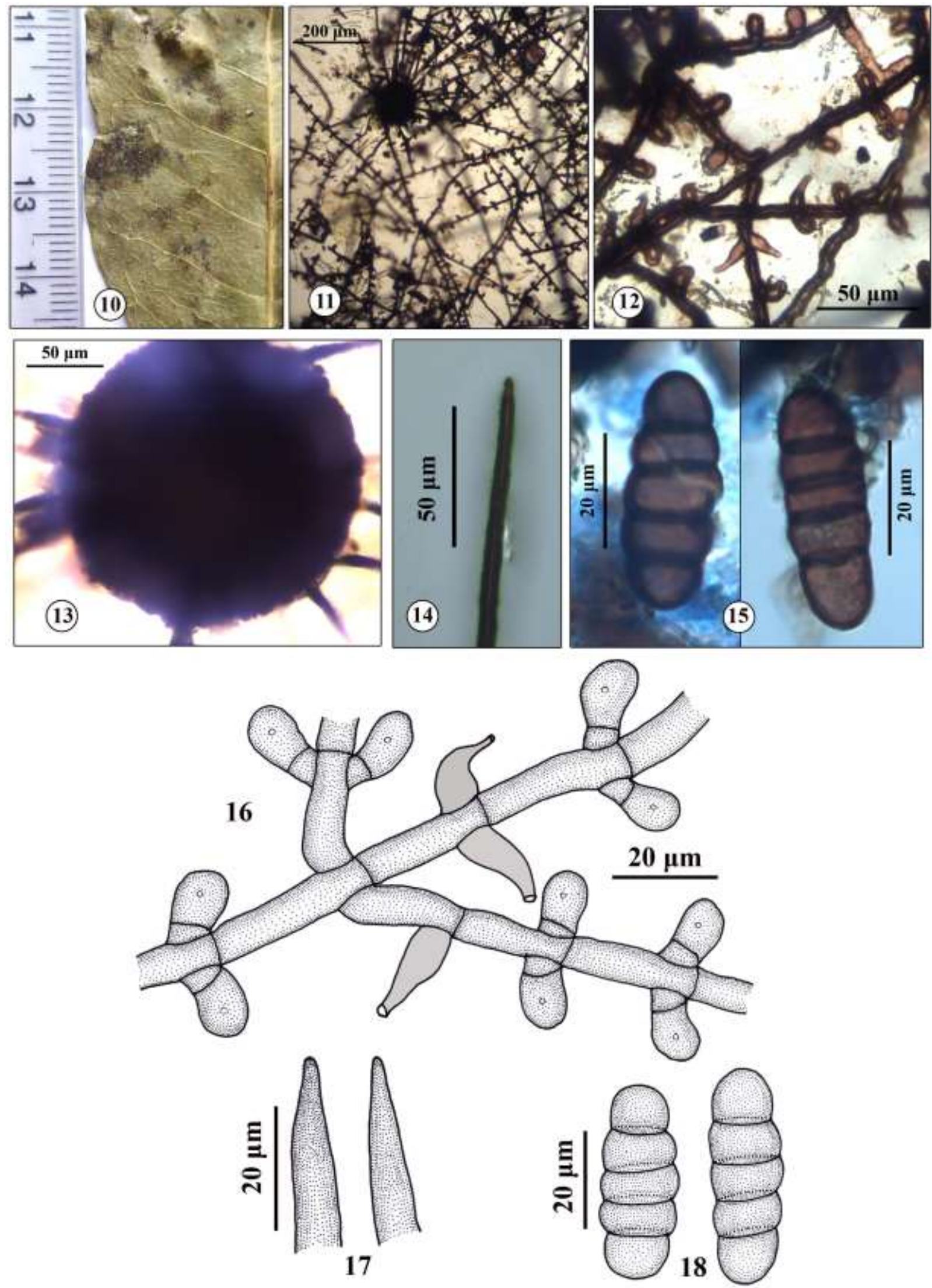

Figs 10-18 - Meliola sideroxyli. 10 Infected leaves. 11 Mycelial colony. 12, 16 Appressoriate mycelium with phialides. 13 Perithecium. 14, 17 Tip of mycelial setae. 15, 18 Ascospores. 
Meliola ventilaginicola Hansf., Proc. Linn. Soc. London 157: 180, 1946; Hansf., Sydowia Beih. 2: 367, 1961.

(Figs. 19-27)

Beeli formula - 3111:4222

Colonies amphigenous, mostly hypophyllous, black brown, subdense, velvety, circular to spreading, confluent, up to $6 \mathrm{~mm}$ in diameter. Hyphae substraight to undulate, branching opposite at acute angles, closely reticulate; cells $20-40 \times 5-7 \mu \mathrm{m}$. Appressoria alternate to subopposite, closely arranged, straight to curved, antrorse, 13-16 $\mu \mathrm{m}$ long; stalk cells cylindrical to cuneate, 4-5 $\times 5-7$ $\mu \mathrm{m}$ long; head cells globose to oblong, entire, 9-11 $\times 9 \mu \mathrm{m}$. Phialides mixed with appressoria, alternate to opposite, straight to curved, ampulliform, 13-21 × 7-9 $\mu \mathrm{m}$. Mycelial setae scattered to grouped around perithecia, straight, simple; acute, pointed to dentate at the tip, up to $432 \mu \mathrm{m}$ long. Perithecia scattered, globose, verrucose at margin, up to $186 \mu \mathrm{m}$ in diameter. Ascospores oblong to cylindrical, olivaceous brown, 4-septate, constricted at the septum, 36-45 × 13-14 $\mu \mathrm{m}$.

Materials examined - India, Maharashtra, Mahabaleshwar, Ambenalighat, on leaves of Ventilago denticulata (Rhamnaceae), 1753'39.9’'N, 73³7'02.6”E, elev. 858 m, 03.11.2013, Bhise M.R., HCIO 51751.

Known distribution - Uganda (Hansford, 1961) and India (the present records).

Notes - Meliola ventilaginicola was known on Ventilago africana from Uganda (Hansford 1961, Far \& Rossman 2014). The present collection matches well with the type description of $M$. ventilaginicola, but, varies in having larger mycelial setae (in contrast up to $280 \mu \mathrm{m}$ long). However, the present species is reported here for the first time from India on hitherto unrecorded host.

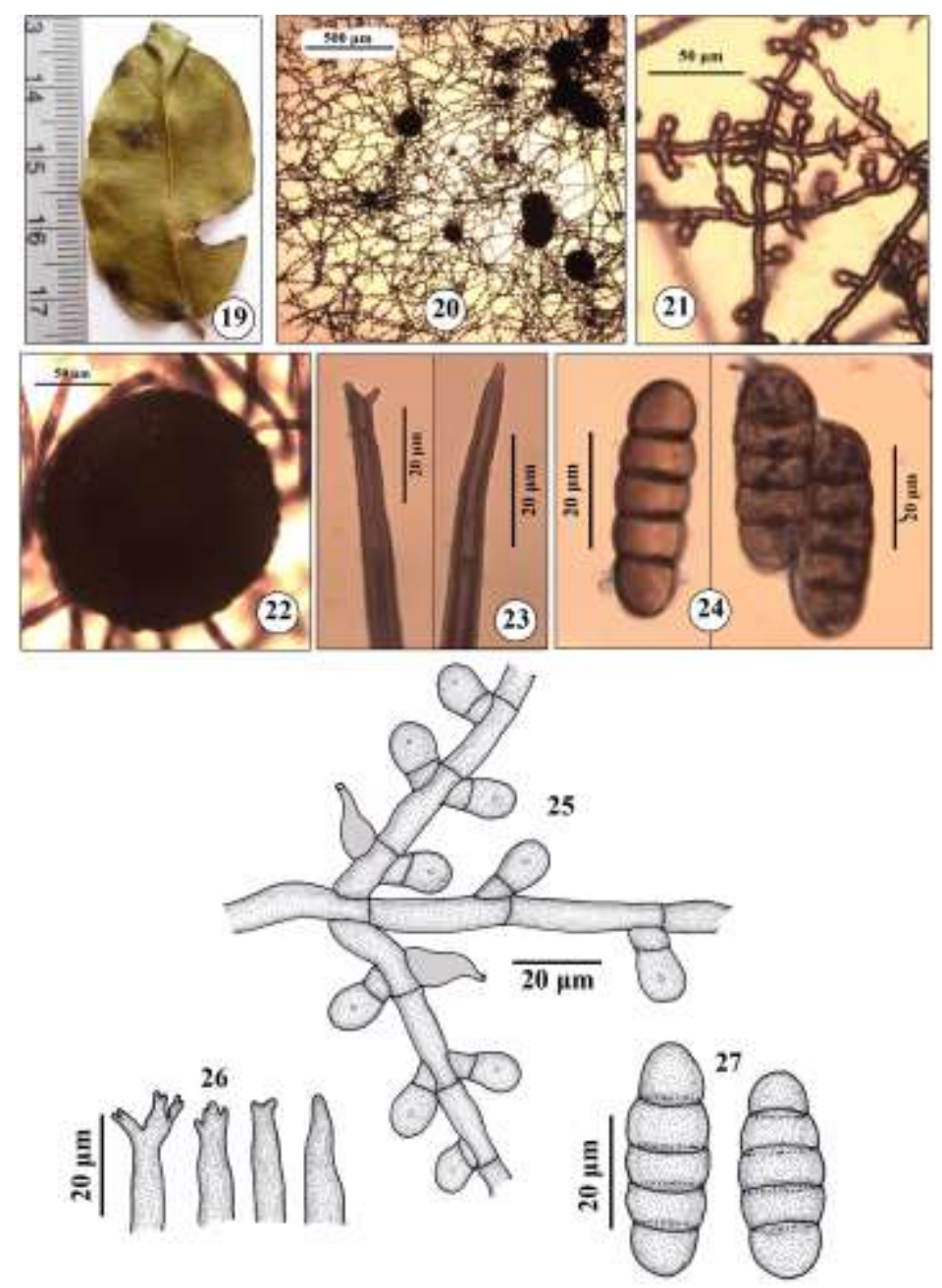


Figs 19-27 - Meliola ventilaginicola. 19 Infected leaves. 20 Mycelial colony. 21, 25 Appressoriate mycelium with phialides. 22 Perithecium. 23, 26 Tip of mycelial setae. 24, 27 Ascospores.

\section{Acknowledgements}

The authors are grateful to authorities of Maharashtra State Biodiversity Board, Nagpur (M.S.) for granting permission for collection of plant material from study area. Thanks are due Prof. S. R. Yadav and Dr. M. M. Lekhak, Dept. of Botany, Shivaji University, Kolhapur for providing the micro-photography facility; Principal, D.K.A.S.C. College, Ichalkaranji and Principal, Krishna Mahavidhyalaya, Shivnagar, Rethare (BK.), Dist. Satara, for providing laboratory facilities.

\section{References}

Bilgrami KS, Jamaluddin S, Rizwi MA. 1991 - Fungi of India. List and References. Today \& Tomorrow's Printers and Publishers, New Delhi. pp. 798.

Bilgrami KS, Jamaluddin, Rizwi MA. 1981 - Fungi of India. Part-II. Today and Tomorrows Printers \& Publishers and Publishers, New Delhi.

Deshpande S, Sharma BD, Nayar MP. 1995 - Flora of Mahabaleshwar and Adjoining's, Maharashtra. vol. I, II. Botanical Survey of India, Calcutta, pp. 776.

Farr DF, Rossman AY. 2014 - Fungal Databases, Systematic Mycology and Microbiology Laboratory, ARS, USDA. Retrieved November 10, 2014, from http://nt.arsgrin.gov/fungaldatabases/

Hansford CG. 1961 - The Meliolineae. A monograph. Sydowia 2, pp. 806.

Hosagoudar VB, Agarwal DK. 2008 - Taxonomic studies of Meliolales. Identification manual. International Book Distributors, Dehradun, India, pp. 263.

Hosagoudar VB, Abraham TK, Pushpangadan P. 1997 - The Meliolinae - A suppliment, Tropical Botanic Garden and Research Institute, Palode, Kerala pp. 201.

Hosagoudar VB. 1996 - Meliolales of India. Botanical Survey of India, Calcutta, pp. 363.

Hosagoudar VB. 2008 - Meliolales of India. vol. II. Botanical Survey of India, Calcutta, pp 390.

Hosagoudar VB. 2013 - Meliolales of India. vol. III. Journal of Threatened Taxa 5(6): 3993-4068; doi:10.11609/JoTT.03307.3993-4068

Jamaluddin S, Goswami MG, Ojha BM. 2004 - Fungi of India 1989-2001. Scientific Publishers, Jodhpur, India. pp. 326. 